\title{
COMPARISON OF A WOODEN HOUSE AND A POROUS CONCRETE MASONRY HOUSE
}

\author{
Pavol ĎURICA ${ }^{1}$, Silvia BAĎUROVÁ ${ }^{*}$, Peter ČASNOCHA ${ }^{1}$
}

\section{Abstract}

This paper deals with an evaluation of an existing wooden panel house and its comparison with alternative material composition (porous concrete masonry house). The criteria for evaluation are the energy performance, size of the usable area, environmental impact and final costs.
Address

1 University of Žilina, Research Centre, Faculty of Civil Engineering, Department of Building Engineering and Urban Planning, Univerzitná 8215/1, 01026 Žilina, Slovakia

Corresponding author: silvia.badurova@rc.uniza.sk

\section{Key words}

- Wooden house,

- porous concrete house,

- environmental indicators $\mathrm{OI3,}$

- building energy balance,

- final costs.

(altitude $375.2 \mathrm{~m}$ a.s.1., outdoor winter design temperature: $-15^{\circ} \mathrm{C}$, average outdoor daytime temperature in the summer: $18.2^{\circ} \mathrm{C}$ ).

The house is a two-storey building of a simple constructional shape. Natural materials were mainly used for its construction. The building is based on foam glass $(d=0.5 \mathrm{~m})$, which is placed on a reinforced-concrete slab $(d=0.2 \mathrm{~m})$. The building takes full advantage of solar heat gains. Wooden windows $\left(U_{w}=0.68-0.82 \mathrm{~W} /\left(\mathrm{m}^{2} . \mathrm{K}\right)\right)$ with

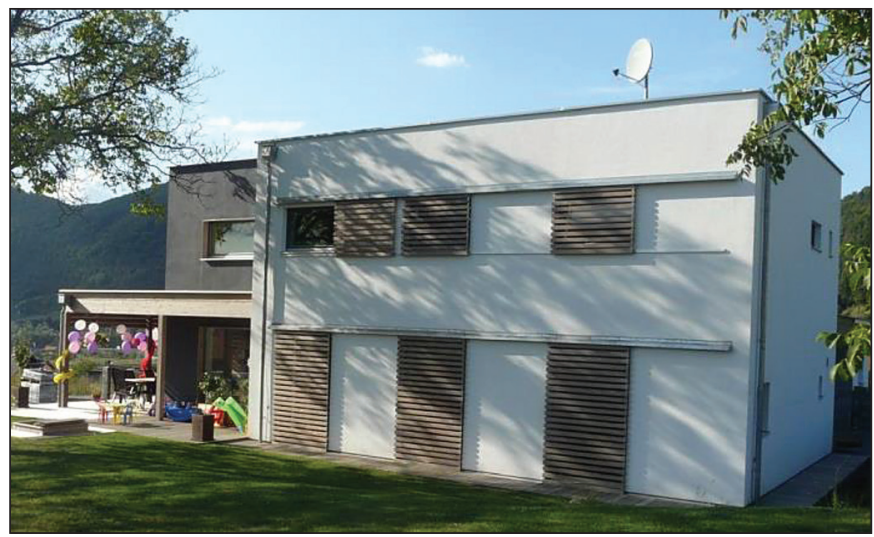

Fig. 1 Southern view of a wooden family house. was designed and built in 2011. It is situated in northern Slovakia

\section{DESCRIPTION OF AN EXISTING FAMILY HOUSE}

The evaluated passive wooden house (referred to as version A) 
1. Clay Plaster

2. Wooden Panel

3. Vapour Barrier

4. Cellulose Insulation

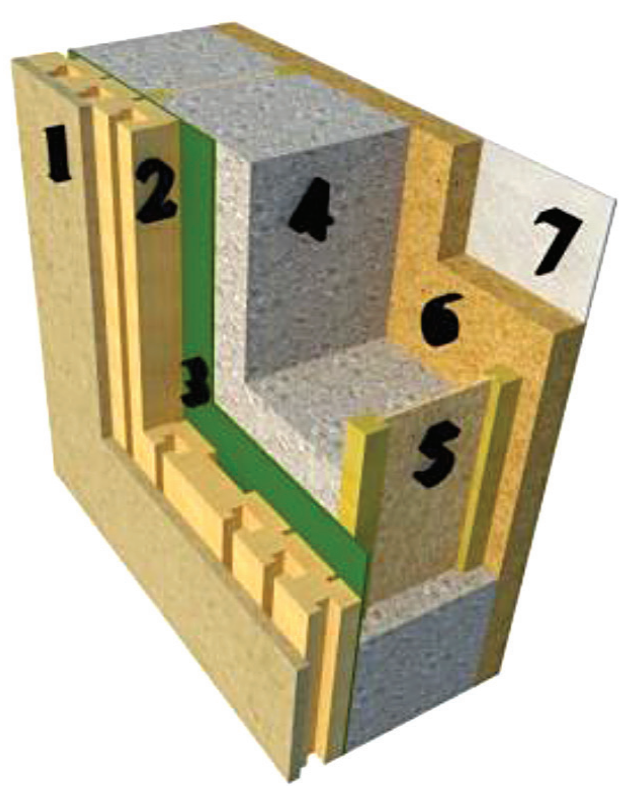

Fig. 2 External Walls, $U=0.107 \mathrm{~W} /(\mathrm{m} 2 . \mathrm{K})$.
1. Wooden Panel

2. Vapour Barrier

3. Graphite Polystyrene

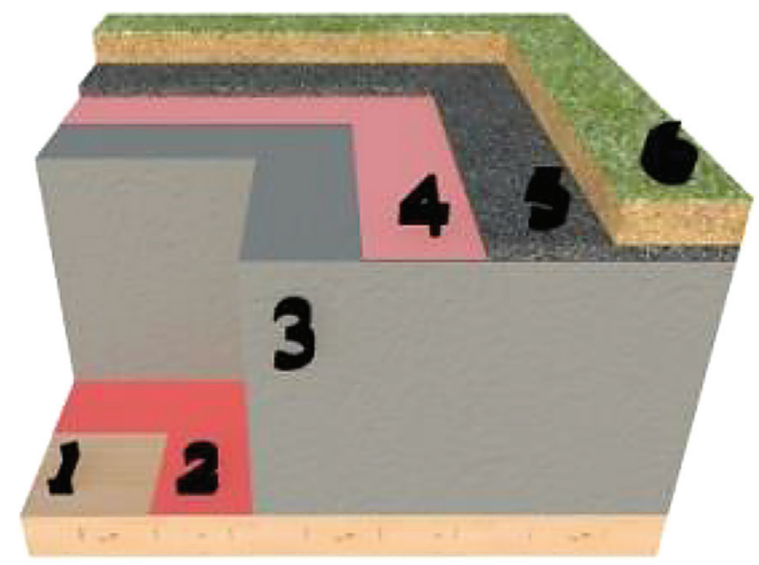

Fig. 3 Roofs, $U=0.066 \mathrm{~W} /(\mathrm{m} 2 . \mathrm{K})$.

triple-glazing are used for fillings. They are protected by an outer shielding, which eliminates overheating of the building in the summer. Part of the southern and western facades is shielded by a terraced roof construction. The compositions of the constructions are shown in Figs. 2-5.

A heat pump, which draws heat from a geothermal source (air to water), provides for the production, distribution and recuperation of heat.

5. Geotextile

6. Extensive Substrate
1. Clay Plaster
4. Expanded Polystyrene
2. Porous Concrete
5. Silicone Plaster

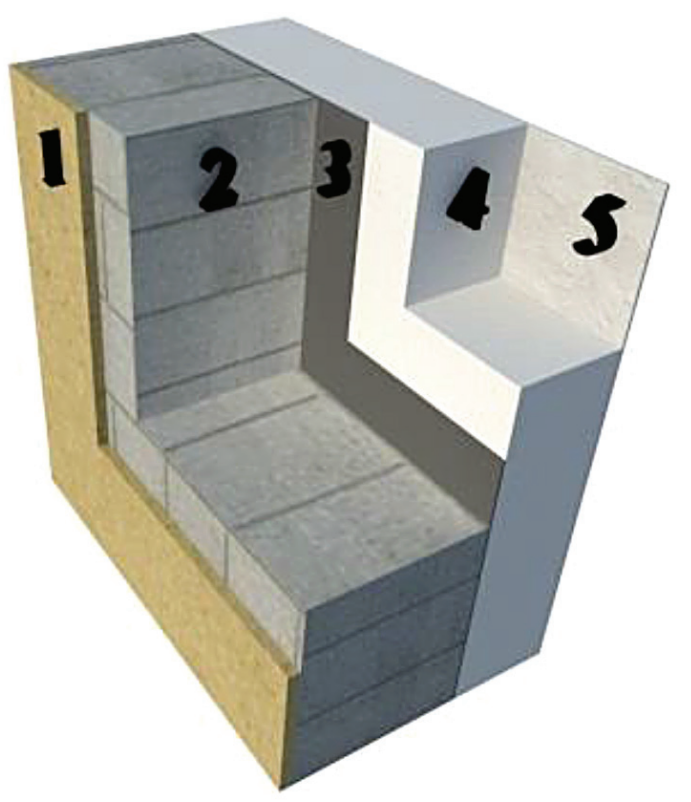

1. Clay Plaster
2. Reinforced Concrete
3. Vapour Barrier

5. Waterproofing

4. Graphite Polystyrene

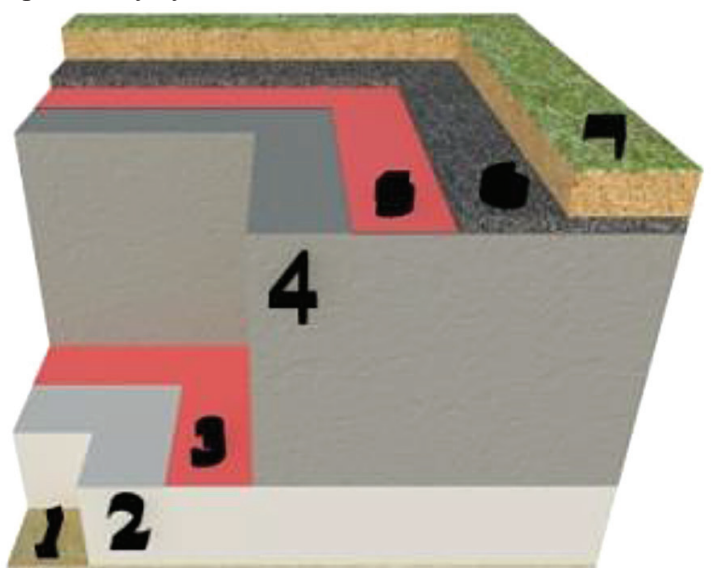

\section{COMPARISON OF THE ACTUAL HOUSE CONSTRUCTIONS AND A VARIANT DESIGN}

According to the project data, a variant design of the family house was created, which is based on porous elements (referred to as version B). The exterior envelope structures are designed in such a way that it could be possible to achieve the same heat transfer coefficient $U\left[\mathrm{~W} /\left(\mathrm{m}^{2} . \mathrm{K}\right)\right]$ (STN 730540, 2012) as in the original structures. The project retained the outer dimensions of the building, the foundation method, the windows, doors, working surface, and the technical solu- 

1. Wooden Panel
2. Gravel
3. Hardboard
4. Hardboard
5. Gypsum Board
6. Floor Pad
7.Wooden Parquet

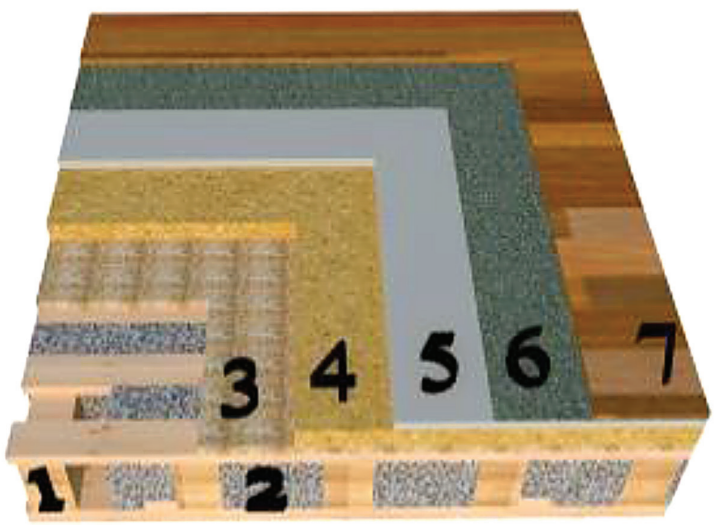

Fig. 4 Internal Ceilings.
1. Plasterboard

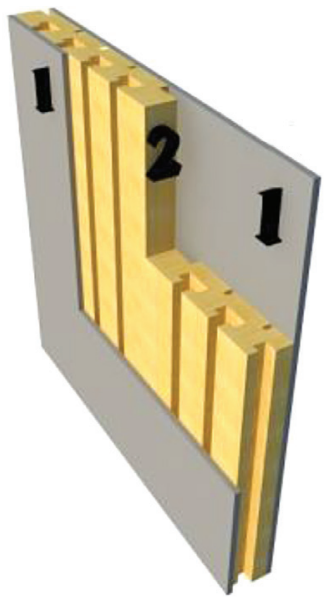

1. Clay Plaster

2. Reinforced Concrete

3. Hardboard

4. Hardboard
5. Gypsum Board

6. Floor Pad

7.Wooden Parquet

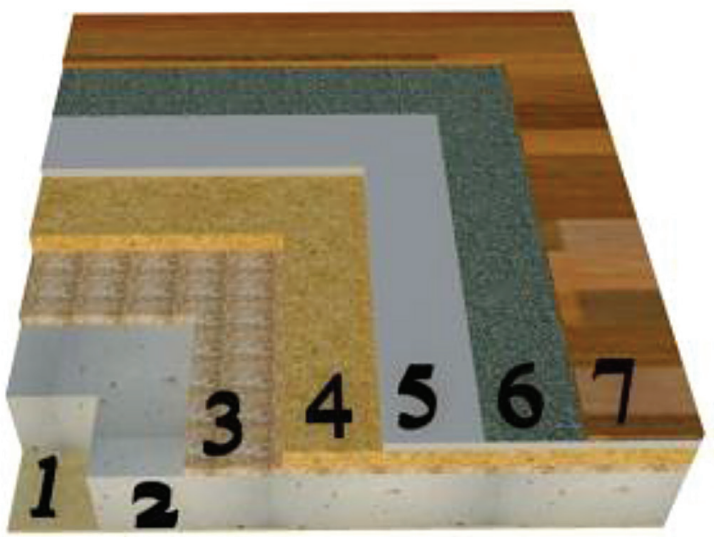
1. Clay Plaster
2. Adobe Bricks
1. Clay Plaster
2. Porous Concrete Blocks

3. Timber Frame
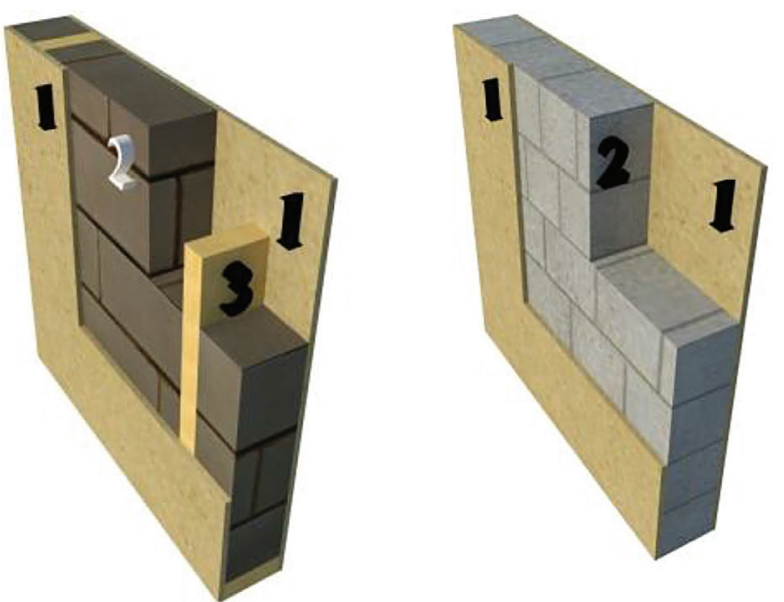

Fig. 5 Internal Walls.

tion. The material compositions of the original and variant constructions are shown in Figs. 1 to 4

\section{COMPARISON OF SPACE}

The thicknesses $d(\mathrm{~m})$ and basis weights $m\left(\mathrm{~kg} / \mathrm{m}^{2}\right)$ of the constructions are described in Tab. 1.

The thickness and weight for $1 \mathrm{~m}^{2}$ of the constructions.

While maintaining the outer dimensions of the building and its disposition, the usable area of Version A is greater by $12 \mathrm{~m}^{2}$ than Version B (Tab. 2).

Tab. 2 Total floor areas and weights of houses.

\begin{tabular}{|l|c|c|c|c|}
\hline Legend & Symbol & Units & Version A & Version B \\
\hline Usable Area & $A_{i}$ & $\mathrm{~m}^{2}$ & 170.56 & 158.59 \\
\hline Material Consumption & $m$ & $\mathrm{~kg} / \mathrm{m}^{2}$ & 891.92 & 1109.37 \\
\hline
\end{tabular}

Tab. 1 The thickness and weight for $1 \mathrm{~m} 2$ of the constructions.

\begin{tabular}{|l|c|c|r|r|}
\hline Legend & Symbol & Units & Version A & Version B \\
\hline \multirow{2}{*}{ External Wall } & $d$ & $\mathrm{~m}$ & 0.482 & 0.630 \\
\cline { 2 - 5 } & $m$ & $\mathrm{~kg} / \mathrm{m}^{2}$ & 124.680 & 265.825 \\
\hline \multirow{2}{*}{ Roof } & $d$ & $\mathrm{~m}$ & 0.625 & 0.710 \\
\cline { 2 - 5 } & $m$ & $\mathrm{~kg} / \mathrm{m}^{2}$ & 84.034 & 163.384 \\
\hline \multirow{3}{*}{ Internal Wall } & $d$ & $\mathrm{~m}$ & 0.291 & 0.280 \\
\cline { 2 - 5 } & $m$ & $\mathrm{~kg} / \mathrm{m}^{2}$ & 255.464 & 162.050 \\
\cline { 2 - 5 } & $m$ & $\mathrm{~m}$ & 0.120 & 0.120 \\
\hline \multirow{2}{*}{ Internal Wall } & $d$ & $\mathrm{~m}$ & 0.180 & 0.180 \\
\cline { 2 - 5 } & $m$ & $\mathrm{~kg} / \mathrm{m}^{2}$ & 281.327 & 133.350 \\
\hline \multirow{2}{*}{ Ground Floor } & $d$ & $\mathrm{~m}$ & 0.774 & - \\
\cline { 2 - 5 } & $m$ & $\mathrm{~kg} / \mathrm{m}^{2}$ & 716.340 & - \\
\hline
\end{tabular}




\section{ENVIRONMENTAL ASSESSMENT}

The environmental appraisal for each construction is compared to the indicator $\mathrm{OI} 3_{\mathrm{KON}}$. A structure's $\mathrm{OI} 3_{\mathrm{KON}}$ as an environmental indicator (for $1 \mathrm{~m}^{2}$ of a structure) encompasses $\mathrm{OI}_{\mathrm{PEI} \text { e }}$ (environmental indicator of non-renewable Primary Energy Input) $\mathrm{OI}_{\mathrm{GWP}}$ (environmental indicator of Global Warming Potential (GWP)), and $\mathrm{OI}_{\mathrm{AP}}$ (environmental indicator of Acidification Potential (AP)), in proportions of one-third each.

This is calculated as shown below (IBO, 2011):

$$
\mathrm{OI}_{\mathrm{KON}}=1 / 3 \mathrm{OI}_{\mathrm{PEI}, \mathrm{ne}}+1 / 3 \mathrm{OI}_{\mathrm{GWP}}+1 / 3 \mathrm{OI}_{\mathrm{AP}} \quad\left[\mathrm{Pts} / \mathrm{m}^{2-}\right.
$$

To convert the MJ per $1 \mathrm{~m}^{2}$ of structure into OIPEI,ne points, the following linear function is used:

$$
\mathrm{f}(\mathrm{x})=1 / 10 *(\mathrm{x}-500) \quad[\mathrm{Pts}]
$$

To convert the $\mathrm{kg} \mathrm{CO} 2$ eq. per $1 \mathrm{~m}^{2}$ of structure into OIGWP points, the following linear function is used:

$$
f(x)=1 / 2 *(x+50) \quad[P t s]
$$

To convert the $\mathrm{kg} \mathrm{SO} 2$ eq. per $1 \mathrm{~m}^{2}$ of structure into OIAP points, the following linear function is used:

$$
f(x)=100 / 0.25^{*}(x-0.21) \quad[\text { Pts }]
$$

\begin{tabular}{|c|c|c|c|c|}
\hline Legend & Symbol & Units & Version A & Version B \\
\hline External Wall & $\mathrm{OI} 3_{K O N}$ & $\mathrm{Pts} / \mathrm{m}^{2}$ & 20 & 68 \\
\hline Roof & $\mathrm{OI} 3_{\mathrm{KON}}$ & $\mathrm{Pts} / \mathrm{m}^{2}$ & 39 & 55 \\
\hline Internal Ceiling & $\mathrm{OI}_{\mathrm{KON}}$ & $\mathrm{Pts} / \mathrm{m}^{2}$ & 16 & 24 \\
\hline Internal Wall 120 & $\mathrm{OI} 3_{\mathrm{KON}}$ & $\mathrm{Pts} / \mathrm{m}^{2}$ & 11 & 11 \\
\hline Internal Wall 180 & $\mathrm{OI} 3_{\mathrm{KON}}$ & $\mathrm{Pts} / \mathrm{m}^{2}$ & 16 & 13 \\
\hline Ground Floor & $\mathrm{OI}_{\mathrm{KON}}$ & $\mathrm{Pts} / \mathrm{m}^{2}$ & 89 & - \\
\hline Windows & $\mathrm{OI} 3_{\mathrm{KON}}$ & $\mathrm{Pts} / \mathrm{m}^{2}$ & 32 & - \\
\hline Door & $\mathrm{OI} 3_{K O N}$ & $\mathrm{Pts} / \mathrm{m}^{2}$ & 29 & - \\
\hline
\end{tabular}

Tab. 3 The results of the environmental potentials for $1 \mathrm{~m}^{2}$ of a construction.

Tab. 4 The results of the environmental potentials for both houses.
The environmental quality of conventional structures is shown by the environmental indicator $\mathrm{OI} 3_{\mathrm{KON}}$ on a scale of 0 to 100 points (Tab. 3). For example, an outside wall with an $\mathrm{OI} 3_{\mathrm{KON}}$ of 70 is typical of a standard structure without any environmental optimizations; an $\mathrm{OI} 3_{\text {KON }}$ of 15 or less can only be attained by means of environmental optimization or by a very light structural design (IBO, 2011).

Buildings are made up of a multitude of different structures. One possible way to determine the environmental potential of a whole building is to use the indicator $\mathrm{OI} 3_{\mathrm{BGX}}$. $\mathrm{An} \mathrm{OI} 3_{\mathrm{BGX}}$ indicator is the area-weighted mean of the $\mathrm{OI}_{\text {KON }}$ values of all the structures contained within an envelope boundary (IBO, 2011).

$$
\mathrm{OI} 3_{\mathrm{BGX}}=\frac{\sum_{i=1}^{N} A_{i} \cdot O I 3_{K O N}}{\sum_{i=1}^{N} A_{i}}[\mathrm{Pts}]
$$

The calculation includes all the materials permanently installed in the house. The lifetime of the building is considered to have a maximum of 50 years. The calculation does not take into account the technical installations, transport and material manipulation on the site.

The results (Tab. 4) indicate that Version A (the wooden house) is the preferable solution with the lowest impacts for all the environmental categories.

\section{BUILDING ENERGY BALANCE ASSESSMENT}

One of the main criteria in the design of a passive house is the requirement that the building must not use more than $15 \mathrm{kWh} /\left(\mathrm{m}^{2} . \mathrm{a}\right)$ in specific heat demands and that the total primary energy (source energy for the electricity, etc.) and consumption (primary energy for heating, hot water and electricity) must not be more than 120 $\mathrm{kWh} /\left(\mathrm{m}^{2} . \mathrm{a}\right)$. The specific heat load for the heating source at the design temperature is recommended, but not required, to be less than

\begin{tabular}{|c|c|c|c|c|}
\hline Legend & Symbol & Units & Version A & Version B \\
\hline Environmental Indicator & $\mathrm{O} / 3_{B G X}$ & Pts & 31 & 51 \\
\hline Annual Material Consumption & PEI & $M J /\left(m^{2} . a\right)$ & 82.29 & 127.97 \\
\hline Annual Bound Production $\mathrm{CO}_{2, \text { eq. }}$ & GWP & $\mathrm{kgCO}_{2, \mathrm{eq} .} /\left(\mathrm{m}^{2} . \mathrm{a}\right)$ & 4.39 & 7.99 \\
\hline Annual Bound ProductionSO & $A P$ & $\mathrm{kgSO}_{2, \mathrm{eq}} /\left(\mathrm{m}^{2} . \mathrm{a}\right)$ & 0.0251 & 0.0283 \\
\hline
\end{tabular}
$10 \mathrm{~W} / \mathrm{m}^{2}$. In warmer climates and/or during the summer months, excessive temperatures may not occur more than $10 \%$ of the time. The build-

\begin{tabular}{|c|c|c|c|c|}
\hline Legend & Symbol & Units & Version A & Version B \\
\hline Enclosed Volume & $V_{i}$ & $m^{3}$ & 451.50 & 414.50 \\
\hline Treated Floor Area & $A_{i}$ & $m^{2}$ & 166.20 & 154.20 \\
\hline Specific Heat Demand & $E_{2}$ & $\mathrm{kWh} /\left(\mathrm{m}^{2} \cdot \mathrm{a}\right)$ & 14.86 & 15.82 \\
\hline $\begin{array}{l}\text { Specific Primary Energy Demand (DHW, Heating, } \\
\text { Cooling, Auxiliary and Household Electricity) }\end{array}$ & $E P_{1}$ & $\mathrm{kWh} /\left(\mathrm{m}^{2} \cdot \mathrm{a}\right)$ & 71.93 & 76.86 \\
\hline Total Emissions $\mathrm{CO}_{2}$-Equivalent & $m_{c 02}$ & $\mathrm{~kg} /\left(\mathrm{m}^{2} . \mathrm{a}\right)$ & 18.81 & 20.10 \\
\hline Heating Load & $P_{H}$ & $\mathrm{~W} / \mathrm{m}^{2}$ & 15.72 & 16.65 \\
\hline Frequency of Overheating & & $\%$ & 2.12 & 2.31 \\
\hline Cooling Load & $P_{c}$ & $\mathrm{~W} / \mathrm{m}^{2}$ & 5.63 & 5.87 \\
\hline
\end{tabular}
ing must not leak more air than 0.6 times the house's volume per hour $\left(\mathrm{n}_{50} \leq 0.61 / \mathrm{h}\right)$ at $50 \mathrm{~Pa}$ or $\mathrm{N} / \mathrm{m}^{2}$, as tested by a Blower door (Feist, 2007).

Tab. 5 The results of the energy balance, PHPP program. 
Since the value $n_{50}$ can be obtained only from direct measurements in situ, it is considered to have a value of $n_{50}=0.61 / \mathrm{h}$ in the computations.

The Passive House Planning Package (PHPP) program was used for the computations of the energy balance of the buildings (based on STN EN ISO 13790, 2009). The results are shown in Tab. 5.

The results of the evaluation indicate that the wooden house (Version A) meets the requirements of a passive house, while the results from the porous house (Version B) indicate that it is a low energy house.

\section{ECONOMIC ASSESSMENT}

The costs for the assessed constructions and their variant solutions were calculated using the CENKROS plus computer programme. The calculations include both material costs and building operating costs.

The resulting values are shown in Tab. 6 and are applied to $1 \mathrm{~m}^{2}$ of the given constructions.

Tab. 6 Total cost of materials and building operations relating to $1 \mathrm{~m}^{2}$ of both constructions.

\begin{tabular}{|c|c|c|}
\hline \multirow{2}{*}{ Construction } & \multicolumn{2}{|c|}{ Total cost without VAT $\left[€ / \mathrm{m}^{2}\right]$} \\
\hline & Version A & Version B \\
\hline External Walls & 117.07 & 103.60 \\
\hline Flat Roof & 93.92 & 102.90 \\
\hline Ceiling & 76.13 & 92.22 \\
\hline Internal Walls 120 & 48.66 & 60.89 \\
\hline Internal Walls 180 & 74.49 & 65.68 \\
\hline
\end{tabular}

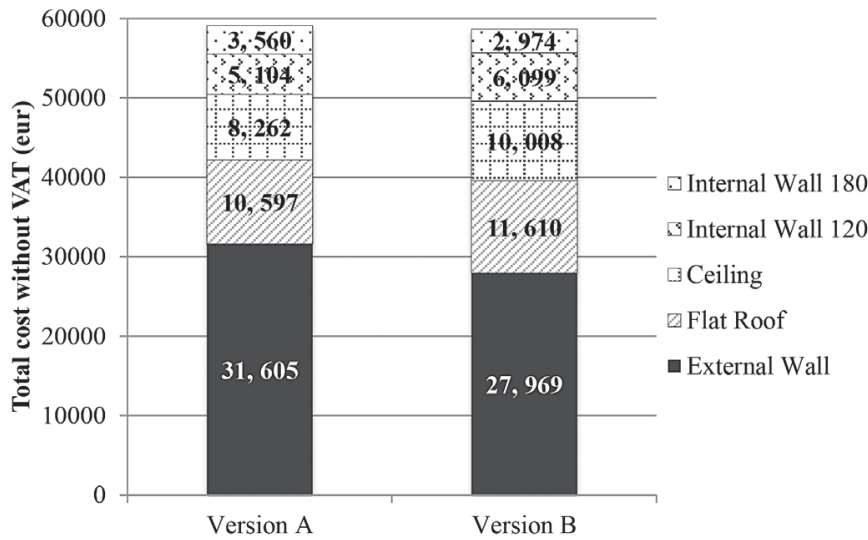

Fig. 6 The resulting comparison of the costs calculated on the total areas of the constructions.

As the versions of the assessed buildings differ only in the structures mentioned above, it is possible to determine the percentage differences without making a detailed budget for the entire buildings (Fig. 6). The porous concrete construction costs (Version B) are lower by $0.8 \%$ than the costs of the wooden house (Version A).

\section{THE RATE OF THE BUILDING OPERATIONS}

The principle behind the rate of the building operations lay in creating an ideal schedule that would constitute a five-day working week and an eight-hour working time.
The building schedule is based on the Critical Path Method (CPM). The critical path represents the shortest possible duration of a project; it means the sections of time that are needed to meet all the project tasks. In this case, the shortest amount of time to complete the building was researched, while only taking the compliance with technological breaks into account and not the season.

When making the concrete and reinforced concrete elements, achieving the required load-bearing capacity was considered after 28 days. In actual conditions, this period can be shortened by using special additives or technologies, while the elements can be loaded after acquiring $60-70 \%$ of the required strength. This amount of time is determined by structural engineers.

The beginning of the construction was considered to be 12.3.2010 for both types of buildings. In a case of continual construction, the wooden house (version A) would have been completed on 11.4.2011, with a 396-day realization. The masonry construction (B version) would have been completed on 07.28.2011, and the duration would have been 504 days.

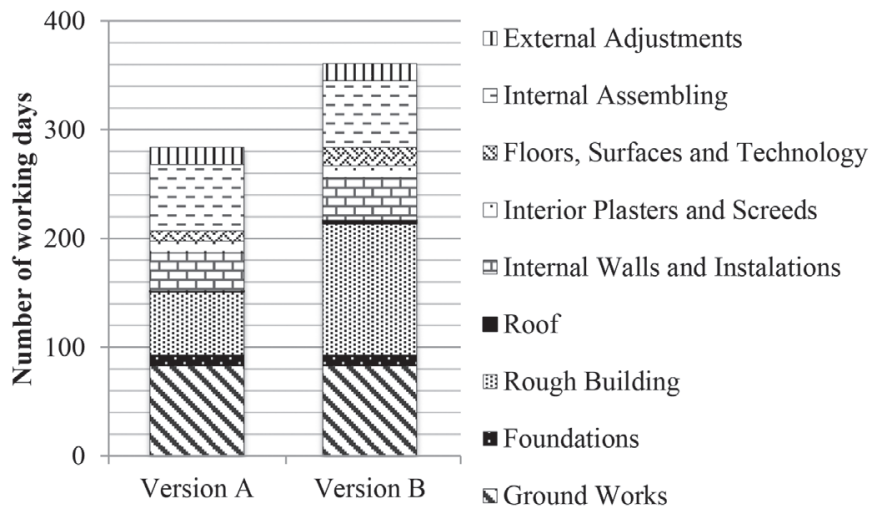

Fig. 7 Time demands for buildings in terms of the number of working days.

Based on the comparison that arises only from the number of working days taken over the timescales (see Fig. 7), the rate of building operations for the wooden construction (version $\mathrm{A}=282$ working days) is 79 days shorter than in the masonry version made of porous concrete blocks (version $\mathrm{B}=361$ working days).

Dry assembly technologies are used in wooden buildings; therefore, the period of construction is obviously shorter (a dry constructional process). The requirement for the rate of building operations is also conditioned by the fact that wooden components must not be exposed to weather influences for a long time. For example, the weather can cause an increase in the moisture in wood, resulting in deformations of the timber after its installation or infestation of the wood by biological pests.

Since wooden components are lightweight, they are easy to assemble. In an actual wooden house, the panels for the walls and ceilings are industrially manufactured, and only one crane, with a lifting capacity of up to 14 tons, was needed during its assembling. The great advantage is also unlimited construction, regardless of the time of year.

As far as a masonry building is concerned, there are different techniques used, in which an amount of water is present in the constructions (a wet constructional process). This type of construction is much more time-consuming and requires more technological breaks; the time necessary for the construction is also limited. For example, in terms of production, transport, storage and treatment of concrete, air temperatures that fall below $0{ }^{\circ} \mathrm{C}$ or rise above $25^{\circ} \mathrm{C}$ at a relative 
humidity below $40 \%$ are considered to be extreme. Concreting in such conditions requires the application of appropriate technological measures to eliminate the adverse effects of low or high temperatures on the quality of concrete and concrete structures, but it is a more capital-intensive way of building.

The technology used for masonry buildings is also more demanding, because not only would a mobile crane be necessary for the building operations, but also other machines such as a concrete mixer and a concrete pump would be needed. However, masonry structures are, compared to wooden houses, more resistant to weathering. When the protection of a structure is done properly, the building operations can be interrupted, even for a longer period of time.

\section{CONCLUSIONS}

Considering that the outer dimensions and dispositions of both assessed family houses remained preserved, wooden houses are the most spacious in terms of useful areas.

Regarding the impact of the buildings on the environment, wooden houses have much better preconditions, mainly in their confrontation with silicate variants. The mining and industrial production of these materials results in high energy and environmental demands. Stores of silicate resources are estimated to last for about 200 years. Lime-sand blocks, which have a markedly better ecological balance than porous concrete blocks, present a more suitable alternative, such as the use of graphitic extruded polystyrene instead of traditional polystyrene (Marceau, 2008).

From the calculations of the material consumption, it is obvious that wooden houses have a much lower weight and, at the same time, much lower requirements for material transport, which has a positive influence on decreasing air pollution. Their liquidation is quite fast; there is the possibility of recycling or changing the building waste into energy during combustion. Masonry houses need more demolition work, and the costs for moving and storing such building waste are higher (Bad’urová, 2013).

The wooden construction seems to be the most expensive alternative in spite of the fact that wooden houses have a higher rate of building works and also have less need for technical equipment at a building site.

The research is supported by the European Regional Development Fund and the Slovak state budget for the projects "Research Centre of University of Žilina”, ITMS 26220220183 and VEGA No. $1 / 0729 / 13$

\section{REFERENCES}

IBO (2011) Guidelines to calculating the OI3 indicators Version 2.2. Österreichisches Institut für Bauen und Ökologie GmbH, Vienna, Austria, 25 pages.

BAĎUROVÁ, S. (2013) Theoretical, technical and technological aspects of the design and production of wood-based buildings. $\mathrm{PhD}$. thesis, University of Žilina, Slovakia, 170 pages.

FEIST, W. (2007) Passive House Planning Package PHPP 2007(SK, CZ). Passivhaus Institut, Darmstadt.

MARCEAU, M. L. - VANGEEM M. G. (2008) Comparison of the Life Cycle Assessments of a Concrete Masonry House and a Wood Frame House. SN3042, Portland Cement Association, Skokie, Illinois, USA, 59 pages.
STN 730540 part 1-3 (2012) Thermal performance of buildings and components. Thermal protection of buildings. Slovak Standards Institute, Bratislava, Slovakia.

STN EN ISO 13790 (2009) Energy performance of buildings. Calculation of energy use for space heating and cooling (ISO 13790:2008). Slovak Standards Institute, Bratislava, Slovakia. 